\title{
SEASONAL CHANGES OF GLYCOGEN CONTENT IN THE HEPATOPANCREAS AND MUSCULATURE OF THE CARP (CYPRINUS CARPIO L.)
}

\section{Z. SVOBODOVÁ}

\author{
Fisheries Research Institute, 38925 Vodňany
}

Received February 7, 1977

\begin{abstract}
Svobodová Z.: Seasonal Changes of Glycogen Content in the Hepatopancreas and Musculature of the Carp (Cyprinus carpio L.). Acta vet. Brno, 47, 1978: 39-50.

The seasonal changes in the mass of hepatopancreas, its absolute and relative amount of glycogen, and hepatopancreas glycogen content per $1 \mathrm{~g}$ body mass were investigated in 1211 carp aged 4 months $\left(K_{\mathrm{r}-1}\right)$ to two years $\left(K_{\mathrm{z}}\right)$. After a sharp increase of these parameters during September and October, the highest glycogen amounts were found in November and December $(28.1 \pm 1.23 \mathrm{~g} ; 5.58 \pm 0.369 \mathrm{~g} ; 19.6 \pm$ $\pm 0.2 \%$ and $13.5 \pm 0.76 \mathrm{mg}$, respectively). After a considerable drop in April and May, the lowest amounts of glycogen were noted in June and July (4.30 士 $\pm 0.200 \mathrm{~g} ; 0.19 \pm 0.018 \mathrm{~g} ; 4.24 \pm 0.326 \%$ and $0.96 \pm 0.117 \mathrm{mg}$, respectively). The parameters under study were closely correlated with water temperature and daylight length.

Glycogen content of the white skeletal musculature, measured in 456 carp, oscillated from $0.34 \pm 0.008 \%$ to $0.81 \pm 0.041 \%$ and was found to be rather independent on the water temperature but highly dependent upon the daylight length. Glycogen content in the red musculature near the lateral line (in 300 carp) oscillated from $1.04 \pm 0.063 \%$ to $2.71 \pm 0.083 \%$ and was found to be highly dependent upon the daylight length. Glycogen content in the heart muscle of 300 carp oscillated from $1.46 \pm 0.077 \%$ to $2.56 \pm 0.049 \%$, and showed a close correlation to water temperature but only a mild one to daylight length.
\end{abstract}

Circannual variations, water temperature, daylight length, carp.

Intensification of fish farming brings about new problems resulting from occurrence of different predisposition factors. Health control in fish farms thus becomes increasingly important. It consists of external indicators such as the volume value and Fulton's conditional index (Krupauer and Hamáčková 1973), and internal indicators such as the dry matter and fat content of the fish body (Vavruška and Janeček senior 1973). Up to now, little attention has been paid to the fish body glycogen content which is the immediate and readily available source of energy for biological processes, and, in addition, the main source of energy in the hypoxic environment; and the only source of energy in the anoxic water environment of the fish.

The aim of the present study was, therefore, to investigate the complex of changes which may occur in the carp farming and are likely to influence the body glycogen stores of the fish (Svobodová 1976). Patterns of seasonal changes in glycogen content of the hepatopancreas, white and the red skeletal musculature and in the heart musculature of the carp are presented in this paper.

\section{Materials and Methods}

In the years 1968-1970, the seasonal cycle of changes in the hepatopancreas mass and its glycogen content was investigated in monthly intervals in carp aged 4 months to 2 years $\left(K_{r-1}\right.$ and $K_{2}$ ) from the experimental ponds No. 70 and No. 64 . The fish were reared under semi-operational 


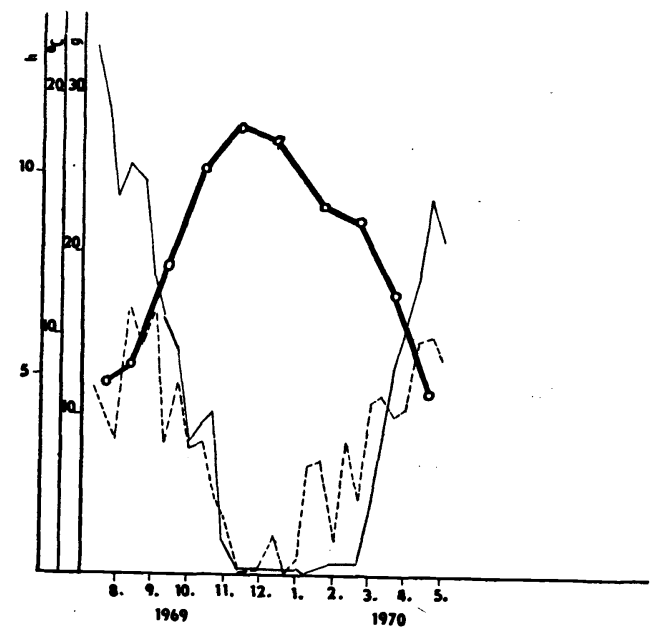

Fig. 1.

Hepatopancreas mass of the carp from the ponds No. 70 and 64, and Nový u Mnišku and Nový u Staňkova.
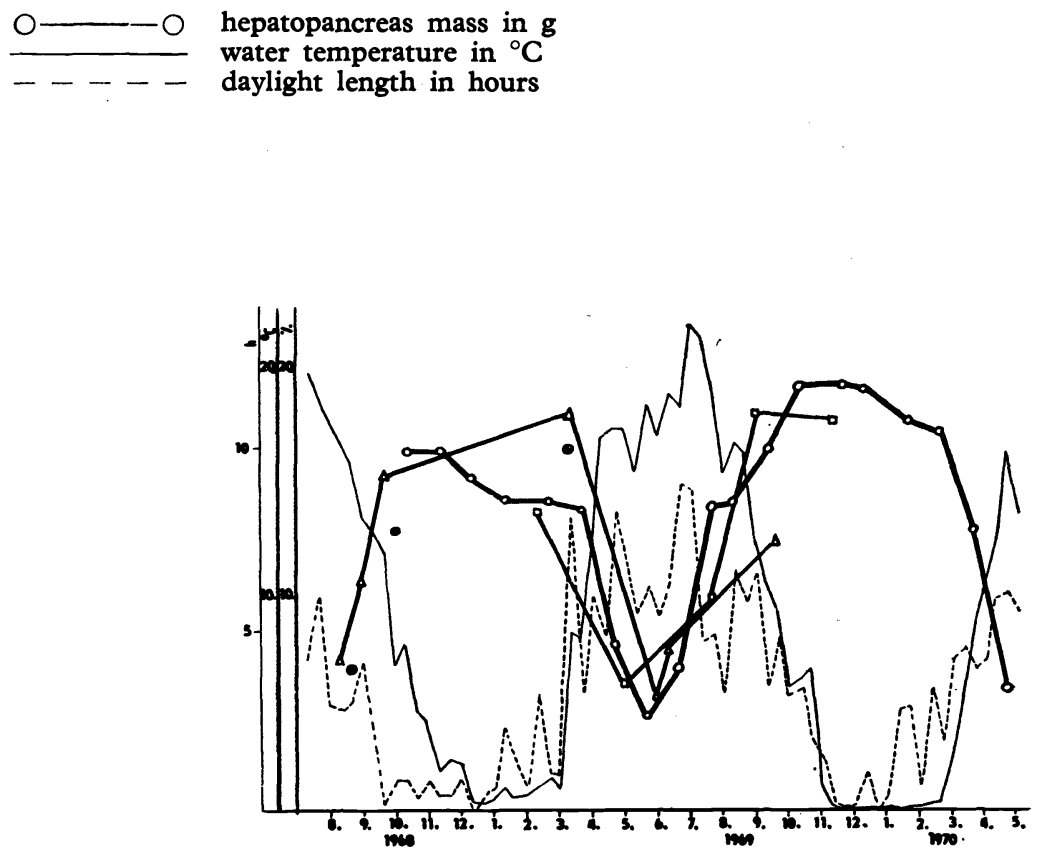

Fig. 2.

Relative glycogen content in hepatopancreas of the carp

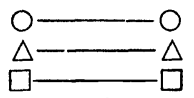

$\oplus$ pond No. 70 pond Nový u Mníšku pond No. 64 pond Nový u Staňkova glycogen in \% 
conditions. Further were analyzed carp from the operational ponds (Nový u Mnišku, Nový u Staňkova). Body mass was recorded in 867 fish, hepatopancreas mass, its relative (in 867 fish) and absolute glycogen content in 171 carp. The second group of carp $\left(K_{1}-K_{2}\right)$ from the experimental ponds No. 66 and 67 was analyzed in the years 1971 and 1972 in monthly intervals. The carp were reared under semi-operational conditions. For analyses, 176 carp from the pond No. 66 and 168 from the pond No. 67 were employed.

The glycogen content of the white skeletal muscular tissue was measured in 456 carp aged 4 months to 2 years $\left(K_{r-1}-K_{2}\right)$, in monthly intervals. The fish were held under semi-operational and operational conditions (ponds No. 70,64; Nový u Mníšku and Nový u Staňkova, resspectively). The glycogen content of the heart muscle and of the red musculature near the lateral line was measured in 300 carp aged 1 to 2 years $\left(K_{1}-K_{2}\right)$. The carp were reared under semi-operational conditions in pond No. 65 and analyzed in monthly intervals.

All specimens were treated as described previously (Svobodová 1976).

During the experimental period, the water temperature was recorded daily (pressure termograph) and the daylight length data for the area were obtained from the Hydrometeorological Institute. In 2-to-4-week long intervals the pond water quality was recorded and according to these data it was maintained at the optimum.

The results of the experiments were evaluated by the simple linear regression method and correlation analyses were made according to Shiler et al. (1967).

\section{Results and Discussion}

The average body mass of the carp $K_{1}-K_{2}$ reared under the operational conditions (ponds Nový u Mníšku, Nový u Staňkova) and under semi-operational conditions (ponds No. 70 and 64) rose during the experimental period from $10.1 \pm 0.77 \mathrm{~g}$ to $472 \pm 29.5 \mathrm{~g}$ (September 1968 to May 1970). Changes in the mass of hepatopancreas (Fig. 1), its relative (Fig. 2) and absolute (Fig. 3) glycogen content and the hepatopancreas glycogen content per $1 \mathrm{~g}$ body mass (Fig. 4) had a similar character during the year. From August till mid-October, a sharp increase of these parameters was noted culminating in December. Later a mild decrease occurred. In April and May a remarkable drop of all the above-mentioned parameters occurred with the lowest values found in June. The average hepatopancreas mass ranged from $11.4 \pm 0.48$ to $28.1 \pm 1.23 \mathrm{~g}$, the relative glycogen amount of hepatopancreas ranged from $5.26 \pm 0.28$ to $19.6 \pm 0.26 \%$, the absolute glycogen amount of this organ ranged from $0.67 \pm 0.044$ to $5.58 \pm$ $\pm 0.369 \mathrm{~g}$, and the glycogen amount per $\mathrm{g}$ body mass ranged from $1.56 \pm 0.083$ to $13.5 \pm 0.76 \mathrm{mg}$.

Between changes in the mass and glycogen content of the hepatopancreas and water temperature and daylight length close to very close correlations were found. The correlation coefficients were $r=-0.92$ (hepatopancreas mass to water temperature), $r=-0.78$ (hepatopancreas mass to daylight length), $r=-0.81$ (relative hepatopancreas glycogen content to water temperature), and $r=-0.84$ (relative hepatopancreas glycogen content to daylight length), $r=-0.88$ (absolute hepatopancreas glycogen content to water temperature) and finally $r=-0.87$ (absolute hepatopancreas glycogen content to daylight length).

The seasonal changes in hepatopancreas mass (Fig. 5), its relative (Fig. 6) and absolute (Fig. 7) glycogen content and hepatopancreas glycogen content per $1 \mathrm{~g}$ body mass (Fig. 8) of the carp $K_{1}-K_{2}$ from the ponds No. 66 and 67 followed almost exactly the pattern observed with the fish from the ponds Nový u Mnišku and Nový u Staňkova. The average values varied as follows: body mass ranged from $44.0 \pm 1.32 \mathrm{~g}$ to $263 \pm 4.8 \mathrm{~g}$ (pond No. 66), and from $93.8 \pm 2.66 \mathrm{~g}$ to $496 \pm 12.3 \mathrm{~g}$ (pond No. 67); hepatopancreas mass ranged from $1.2 \pm 0.06 \mathrm{~g}$ to $10.0 \pm 0.54 \mathrm{~g}$ (pond No. 66), and from $2.5 \pm 0.12$ to $25.3 \pm 0.74 \mathrm{~g}$ (pond No. 67); the relative glycogen content of hepatopancreas ranged from $4.24 \pm$ 


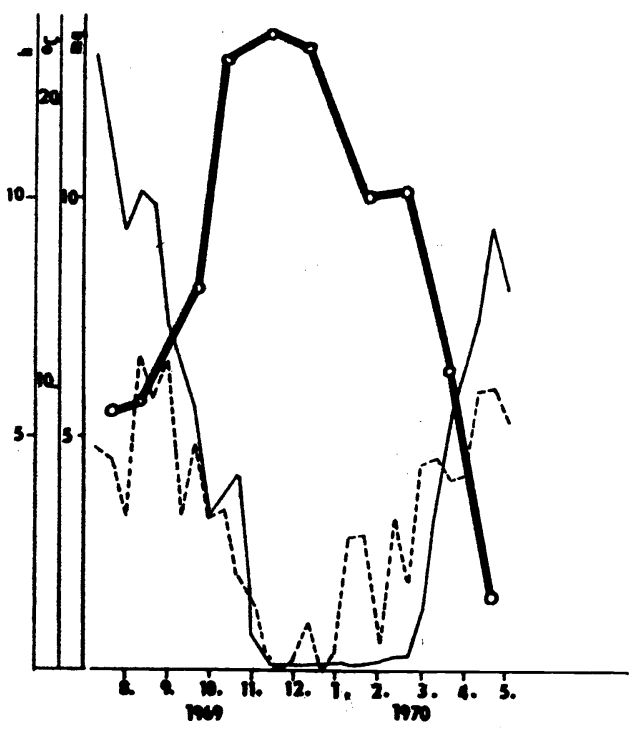

Fig. 3.

Absolute glycogen content in hepatopancreas of the carp

$\mathrm{O}-\mathrm{O}$ glycogen in $\mathbf{g}$

water temperature in ${ }^{\circ} \mathbf{C}$
daylight length in hours

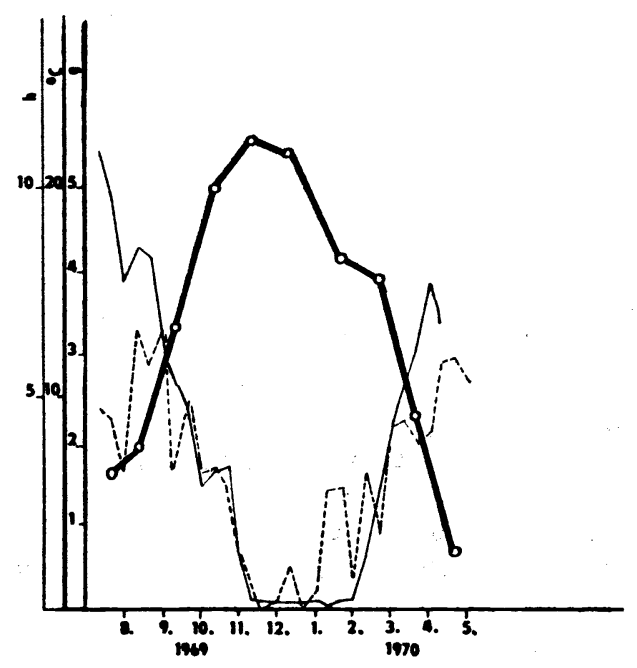

Fig. 4.

Glycogen content in hepatopancreas per $1 \mathrm{~g}$ body mass of the carp

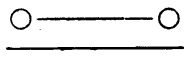




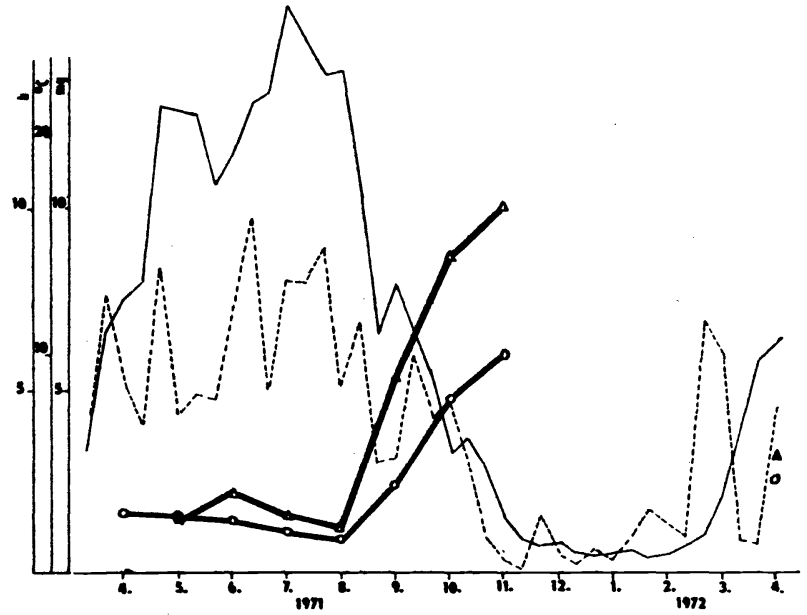

Fig. 5.

Hepatopancreas mass of the carp from the ponds No. 66 and 67 $\left.\begin{array}{l}\text { pond No. } 66 \\ \text { pond No. } 67\end{array}\right\}$ hepatopancreas mass in $\mathrm{g}$ water temperature in ${ }^{\circ} \mathrm{C}$ daylight length in hours

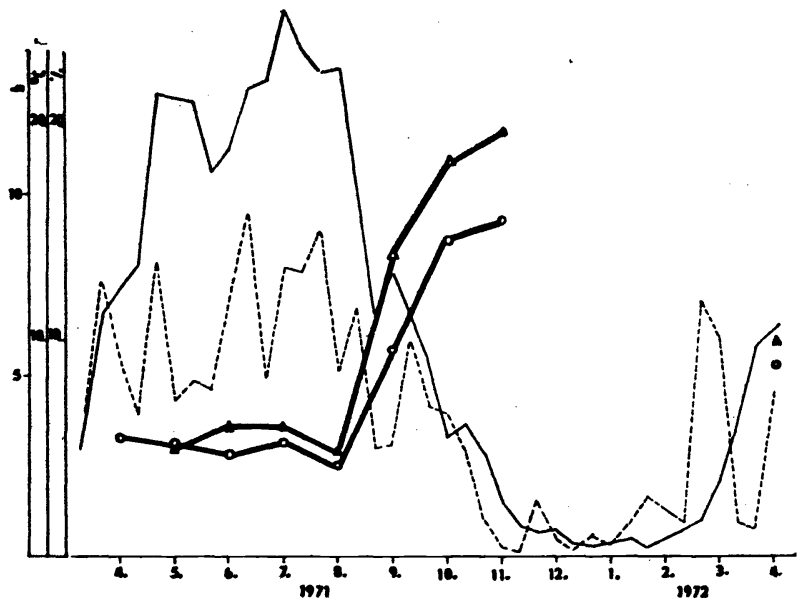

Fig. 6.

Relative glycogen content in hepatopancreas of the carp

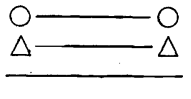

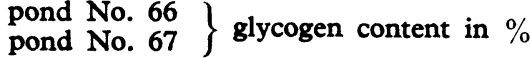

water temperature in ${ }^{\circ} \mathrm{C}$

- - - - daylight length in hours 
\pm 0.326 to $15.5 \pm 0.54 \%$ (pond No. 66) and from $4.75 \pm 0.420$ to $19.5+$ $\pm 0.36 \%$ (pond No. 67); the absolute glycogen amount in the hepatopancreas ranged from $0.07 \pm 0.004$ to $1.59 \pm 0.134 \mathrm{~g}$ (pond No. 66) and from $0.13 \pm$ \pm 0.011 to $4.96 \pm 0.195 \mathrm{~g}$ (pond No. 67); the hepatopancreas glycogen amount per $1 \mathrm{~g}$ body mass ranged from $0.96 \pm 0.117$ to $6.07 \pm 0.515 \mathrm{mg}$ (pond No. 66) and from $1.24 \pm 0.126$ to $10.1 \pm 0.44 \mathrm{mg}$ (pond No. 67).

In the carp from the ponds No. 66 and 67 close correlation was found between water temperature and hepatopancreas mass $(r=-0.75 ; r=-0.70)$, between water temperature and relative hepatopancreas glycogen amount $(r=-88$; $\mathbf{r}=-0.70$ ), between water temperature and the absolute hepatopancreas glycogen amount $(r=-0.70 ; r=-0.70)$, and a very close correlation between water temperature and glycogen in hepatopancreas per $1 \mathrm{~g}$ of body mass $(r=-0.93$; $r=-0.85$ ). Close correlation was also found in $K_{1}-K_{2}$ from these ponds between the daylight length and hepatopancreas mass $(r=-0.75 ; r=-0.74)$, the dayligh length and relative and absolute glycogen amount in the hepatopancreas $(r=-0.81, r=-70 ; r=-0.70, r=-0.74)$, further between the daylight length and hepatopancreas glycogen content per $1 \mathrm{~g}$ body mass $(r=$ $=-0.70 ; r=-0.75)$.

These data are in good agreement with those found in literature. The seasonal changes in hepatopancreas mass agree with the relative hepatopancreas mass changes (Svobodová and Kocová 1975) during the first two years of life of the carp. Glycogen accumulation in the carp hepatopancreas occurs in autumn and its amount again decreases in the spring (Albrecht 1966, 1967a; Gerasimova 1970; Gas and Serfaty 1972; Sherstneva 1972 and Fekete 1971). This fact was fully confirmed in our studies in fish under both semi-operational and operational conditions.

The annual pattern of changes in hepatopancreas mass and its glycogen content is the same; the close correlations can be explained by the direct influence of the glycogen amount on the hepatopancreas mass, and of the glycogen-influenced water retention in this organ (Albrecht 1967b; Svobodová 1977).

Glycogen content in the white musculature of the carp $K_{r-1}$ to $K_{2}$ reared under the operational conditions (in ponds Nový u Mnišku, Nový u Staňkova) and under the semi-operational conditions (ponds No. 70 and 64) showed a certain rhythmicity during the experimental period of 1968-1970. The glycogen content of the white muscles followed the above-mentioned pattern of seasonal changes and it ranged from $0.34 \pm 0.008$ to $0.81 \pm 0.041 \%$ (Fig. 9). Dependence of the glycogen content in the white musculature on water temperature was only mild $(r=-0.46)$, on the daylight length high $(r=-0.66)$.

In the fish $K_{1}-K_{2}$ analyzed for the glycogen content in the heart muscle and in the red musculature of the lateral line was the average weight in April $197144 \pm 1.33 \mathrm{~g}$, and at the last fishing in June 1972 it was $548 \pm 14.3 \mathrm{~g}$. A significant decrease in the glycogen content of the heart muscle was noted in June $(1.74 \pm 0.0049 \%)$ and the lowest value was found in July $(1.65 \pm$ $\pm 0.049 \%$ ). In August again a sharp increase occurred $(2.22 \pm 0.059 \%)$, and from September to April of the following year it oscillated between $2.18 \pm$ \pm 0.065 and $2.56 \pm 0.066 \%$; a sharp decrease was noted in May and June $(1.46 \pm 0.077 \%)$, see Fig. 10. High dependence of the heart glycogen content upon the water temperature was found $(r=-0.68)$, while only a mild correlation between the heart glycogen content and daylight length $(r=-0.43)$ was noted. 


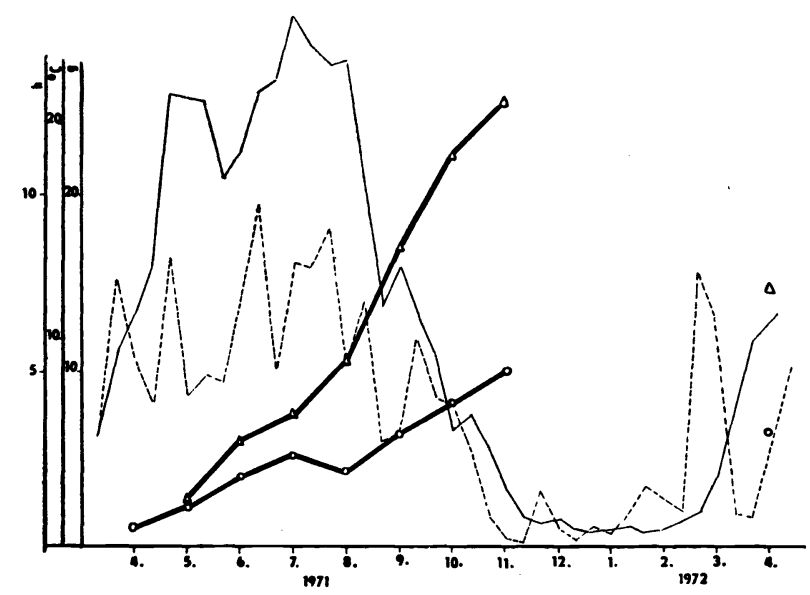

Fig. 7.

Absolute glycogen content in hepatopancreas of the carp water temperature in ${ }^{\circ} \mathrm{C}$

$\overline{----\overline{0}}$
$\square \longrightarrow \Delta$ daylight length in hours $\left.\begin{array}{l}\text { pond No. } 66 \\ \text { pond No. } 67\end{array}\right\}$ glycogen in $\mathrm{g}$

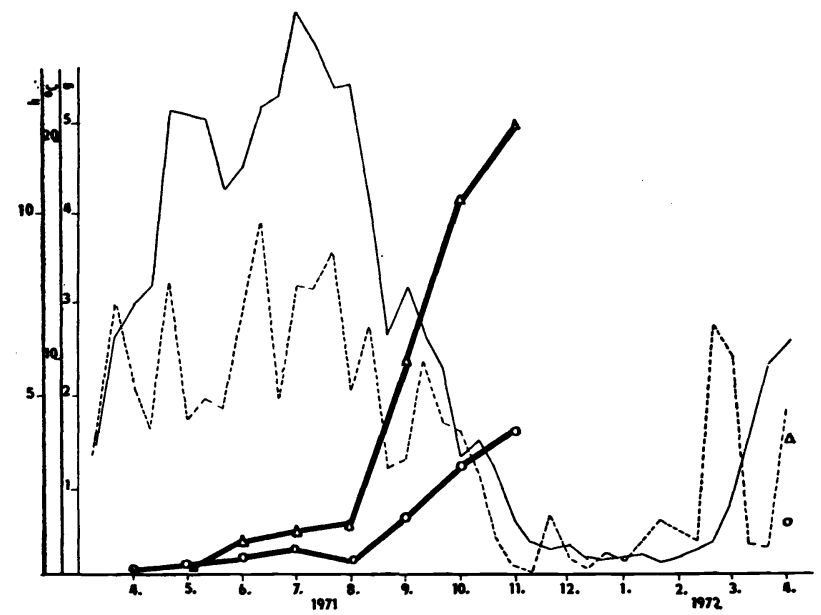

Fig. 8.

Glycogen content in hepatopancreas per $1 \mathrm{~g}$ body mass of the carp

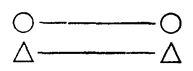
$\left.\begin{array}{l}\text { pond No. } 66 \\ \text { pond No. } 67\end{array}\right\}$ glycogen in $\mathrm{mg}$ water temperature in ${ }^{\circ} \mathrm{C}$

- $\ldots+\ldots$ daylight length in hours 
More pronounced seasonal variations were found in the glycogen content of the red musculature near the lateral line of the carp. Its significant decrease occurred in June $(1.35 \pm 0.086 \%)$ with a minimum in July $(1.04 \pm 0.063 \%)$. In August and September it increased again $(1.77 \pm 0.135$ to $2.26 \pm 0.141 \%)$. From October to March the glycogen content in musculature near the lateral line escillated from $2.19 \pm 0.088$ to $2.71 \pm 0.083 \%$, and in the following months

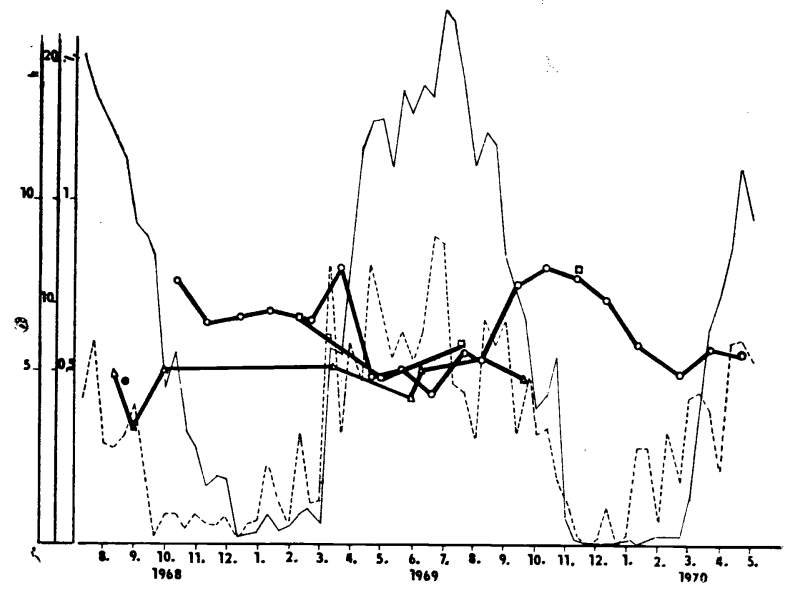

Fig. 9.

Glycogen content in the white skeletal musculature of the carp

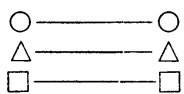

$\oplus$ pond No. 70 pond No. 64 pond Nový u Mnišku pond Nový u Staňkova water temperature in ${ }^{\circ} \mathrm{C}$ daylight length in hours

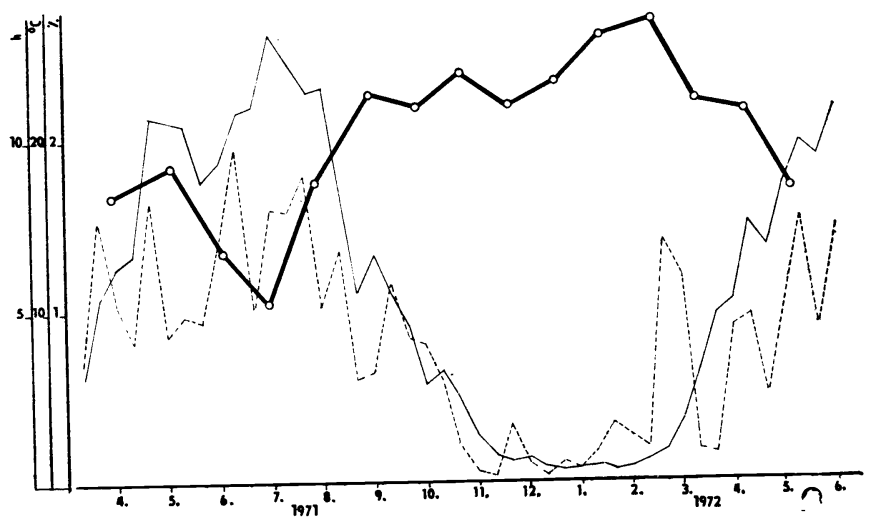

Fig. 10.

Glycogen content in the heart muscle of the carp

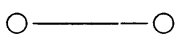
glycogen in \% water temperature in ${ }^{\circ} \mathrm{C}$ daylight length in hours 
a sharp decrease to $1.70 \pm 0.153 \%$ occurred (Fig. 11). This glycogen content was very closely correlated to water temperature during the year $(r=-0.84)$ and closely correlated to the daylight length $(r=-0.67)$.

In literature, no mention of detailed studies of seasonal changes in glycogen content of the white, red and heart muscles of the carp was found. Only Shers tneva (1975) observed a decrease in glycogen content of the white and red muscles in May. Seasonal rhythms in glycogen content in the white skeletal and heart muscles of the tench were studied by Demael - Suard and Pérés (1964). They found a low glycogen content in the white musculature with small seasonal variations. The heart muscle glycogen content varied during the year from 1.5 to $5 \%$.

In our study, moderate to close correlation between the glycogen content in the white, red and heart musculature of the carp and water temperature and daylight length was found. The most pronounced seasonal changes were observed with the red musculature near the lateral line. Similar conclusion was reached

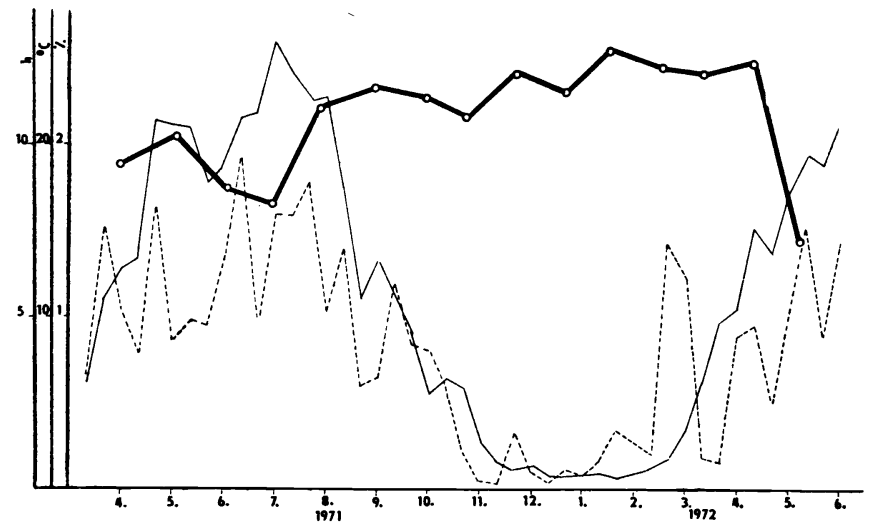

Fig. 11.

Glycogen content in the red musculature near the lateral line of the carp

$\mathrm{O}-\mathrm{O}$ glycogen in $\%$

water temperature in ${ }^{\circ} \mathrm{C}$

daylight length in hours

also by Wittenberger and Diaciuc (1965) and Pora et al. (1971) who found great differences in metabolic rate of the white and red muscle tissue, and similar metabolic rate in the red muscles and liver of the fish.

In the present study, made in various vegetation periods and under different rearing conditions, moderate to very close correlation between the glycogen content in the organs under study and water temperature and daylight length was observed. The influence of water temperature on the seasonal biorhytms in the fish was observed by other authors (Albrecht 1966, 1967a). According to Pavlovič (1968), one of the most important factors is the light. On the basis of own observations Waitzenegger and Serfaty (1967) described the existence of circannual endogenous rhythms in the fish. Our observations serve to support these findings. 


\section{Obsah glykogenu v hepatopankreatu a ve svalovině kaprů (Cyprinus carpio L.) v prủběhu roku}

Sezónní cyklus hmotnosti hepatopankreatu, relativního a absolutniho množství glykogenu $\mathrm{v}$ hepatopankreatu a glykogenu hepatopankreatu na gram hmotnosti těla byl sledován u 1211 kusů kapra věkových kategorií $K_{r-1}-K_{2}$. Změny jednotlivých sledovaných ukazatelů $\mathrm{v}$ průběhu roku byly stejného charakteru. $\mathrm{K}$ jejich prudkému vzestupu docházi $\mathrm{v}$ prủběhu měsíce září a řijna, nejvyšší hodnoty byly dosaženy $\mathrm{v}$ listopadu a $\mathrm{v}$ prosinci (hmotnost hepatopankreatu $28,1 \pm 1,23 \mathrm{~g}$, relativní množství glykogenu $\mathrm{v}$ hepatopankreatu $19,6 \pm 0,26 \%$, absolutní množství glykogenu $\mathrm{v}$ hepatopankreatu $5,58 \pm 0,369 \mathrm{~g}$, množství glykogenu hepatopankreatu na gram hmotnosti těla $13,5 \pm 0,76 \mathrm{mg}$ ); v následujícím období nepatrně poklesly. $K$ velmi prudkému poklesu hodnot jednotlivých ukazatelů dochází v prủběhu měsíců dubna a května; nejnižší hodnoty byly zaznamenány $\mathrm{v}$ červnu a $\mathrm{v}$ červenci (hmotnost hepatopankreatu 4,30 \pm $\pm 0,200 \mathrm{~g}$, relativní množství glykogenu $\mathrm{v}$ hepatopankreatu $4,24 \pm 0,326 \%$, absolutní množství glykogenu v hepatopankreatu $0,19 \pm 0,018 \mathrm{~g}$, množství glykogenu hepatopankreatu na gram hmotnosti těla $0,96 \pm 0,117 \mathrm{mg}$ ). Byla prokázána vysoká až velmi vysoká korelace mezi jednotlivými sledovanými ukazateli a teplotou vody a délkou slunečního svitu.

Obsah glykogenu v bílé kosterní svalovině 456 kaprů $K_{r-1}-K_{2}$ se v průběhu roku pohyboval $\mathrm{v}$ rozmezí hodnot $0,34 \pm 0,008-0,81 \pm 0,041 \%$. Závislost změn obsahu glykogenu $v$ bílé svalovině na teplotě vody je mírná, na délce slunečního svitu význačná. Sezónní změny byly zjištěny i u glykogenu ve svalovině srdce 300 kusů kaprů $K_{1}-K_{2}$, obsah kolísal v rozmezí $1,46 \pm 0,077-2,56 \pm$ $\pm 0,049 \%$. Vztah obsahu glykogenu $\mathrm{v}$ srdečni svalovině $\mathrm{k}$ teplotě vody byl význačný, $\mathrm{k}$ délce slunečního svitu mírný. Výraznější sezónní kolísání bylo nalezeno u glykogenu červené svaloviny v okolí postranní čáry 300 kaprů $K_{1}-K_{2}$; nejnižší obsah byl $1,04 \pm 0,063 \%$, nejvyšší obsah $2,71 \pm 0,083 \%$. Závislost množství glykogenu $\mathrm{v}$ červené svalovině kaprů $\mathrm{v}$ průběhu roku na teplotě vody byla vysoká, na délce slunečního svitu význačná.

\section{Содержание гликогена в гепатопанкреасе и в мышечной ткани карпов} (Cyprinus carpio L.) в течение года

Сезонный цикл массы гепатопанкреаса, относительного и абсолютного количества гликогена в гепатопанкреасе и гликогена гепатопанкреаса на грамм массы тела исследовались на 1211 карпах возрастных категорий $\mathrm{K}_{r-1}-\mathrm{K}_{2}$. Изменения отдельных наблюдаемых показателей в течение года были одинакового характера. Их резкое увеличение наблюдается в течение сентября и октября, максимальных величин было достигнуто в ноябре и декабре (масса гепатопанкреаса $28,1 \pm 1,23$ г, относительное количество гликогена в гепатопанкреасе $19,6 \pm 0, \overline{26} \%$, абсолютное количество гликогена в гепатопанкреасе $5,58 \pm 0, \overline{36} 9$ г, количество гликогена в гепатопанкреасе на грамм массы тела $13,5 \pm 0,76$ мг); в последующий период настоящие величины незначительно понизились. Резкое понижение величин отдельных показателей наблюдается в течение апреля и мая; минимальные величины были отмечены в июне и июле (масса гепатопанкреаса $4,30 \pm 0,200$ г, относительное количество гликогена в гепатопанкреасе $4,24 \pm 0, \overline{32} 6 \%$, абсолютное количество гликогена в гепатопанкреасе $0,19 \pm 0,0 \overline{18}$ г, количество гликотена 
гепатопанкреаса на грамм массы тела 0,96 0,117 мг). Была установлена высокая даже очень высокая корреляция между отдельными наблюдаемыми показателями, температурой воды и продолжительностью света солнца.

Содержание гликогена в белой скелетной мышечной ткани 456 карпов $K_{r-1}-K_{2}$ в течение года достигало пределов величин $0,34 \pm 0,008-0,81 \pm$ $\pm 0,041 \%$. Зависимость изменений содержания гликогена в белой скелетной мышечной ткани от температуры воды незначительная, от продолжительности света солнца - значительна. Сезонные изменения были также выявлены в мышечной ткани сердца 300 карпов К1 - К2, содержание коле-

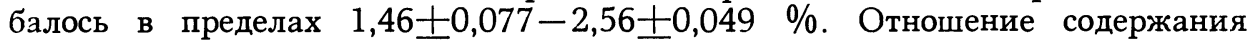
гликогена мышечной ткани сердца к температуре воды было значительным, к продолжительности света солнца - незначительным. Более существенное сезонное колебание было установлено у гликогена красной мышечной ткани около посторонней линии 300 карпов К1 - К2; самое низкое содержание было отмечено $1,04 \pm 0,063 \%$, самое высокое $-2,71 \pm 0,083 \%$. Зависимость количества гликогена в красной мышечной ткани карпов от температуры воды в течение года была высокой, от продолжительности света солнца - значительной.

\section{References}

ALBRECHT, M. L.: Winterruhe und Kohlenhydratstoffwechsel des Karpfens (Cyprinus carpio L.). Dtsch. Fisch. Ztg. 13, 1966: 106-109.

ALBRECHT, M. L.: Beobachtungen über den Eiweiss und Kohlenhydratstoffwechsel des Karpfens (Cyprinus carpio L.) im 1. und 2. Aufzuchtjahr. Z. Fisch., 14, 1967a: 248-276.

ALBRECHT, M. L.: Normale und krankhafte Veränderungen der Karpfenleber. Dtsch. Fisch. Ztg., 14, 1967b: $231-240$.

DEMAEL-SUARD, A. - PÉRÉS, G.: Les variations des réserves en glycogene de la Tanche (Tinca tinca L.) an cours de l'années. J. Physiol., Paris, 56, 1964: 336.

FEKETE, J.: Különféle halfajok májglikogénjének évszakos változatai. Hálászat, 17, 1971 : 90-91.

GAS, N. - SERFATY, A.: Cytophysiologie du foie de carpe. Modifications ultrastructurales consécutives au maintien dans des conditions de jeune hivernal. J. Physiol., 64, 1972: 57-67.

GERASIMOVA, T. D.: Vlijanije uslovij vyraščivanija na uglevodnyj obmen u dvuchletkov češujčatogo karpa. Izvestija TSCHA, Moskva, 1970: 200-209.

KRUPAUER, V. - HAMÁČKOVÁ, J.: Závislost mezi exteriérem a individuální vahou dvouletých kaprů. Buletin VÚRH Vodňany, 9, 1973: 3-11.

PAVLOVIC,, V.: Die jahreszeitlichen Schwankungen des Blutzuckerspiegels und des Leberglykogens von Thymalus thymalus $\mathrm{L}$. und Salmo trutta $\mathrm{m}$. fario $\mathrm{L}$. bei nahezu konstanter Temperatur des Wassers. Z. Vergl. Physiol., 59, 1968: 72-77.

PORA, E. A. - GÁBOS, M. - POPU, C. A.: Actinuea tiroxinei, tiouracilului si a TSH asupra metabolismului glucidic la Cyprinus carpio L. Stud. cer. biol., Sér. Zool., 23, 1971: 105-110.

SVOBODOVÁ, Z.: Glukóza a glykogen u kapra (Cyprinus carpio L.). PhD. thesis, VÚHR Vodňany, VŠV Brno 1976, $161 \mathrm{pp}$.

SVOBODOVÁ, Z.: Hepatopankreas kapra: vztah hmotnosti k obsahu glykogenu. Bulletin VÚRH Vodňany, 13, 1977: 22-24.

SVOBODOVÁ, Z. - KOCOVÁ, A.: Relativní hmotnost vnitřních orgánů kapra v průběhu roku. Bulletin VÚRH Vodňany, 11, 1975: 13-17.

SVOBODOVÁ, Z. - VAVRUŠKA, A.: Rozložení glykogenu v přičně pruhované svalovině kapra (Cyprinus carpio L.) Bulletin VUURH Vodňany, 11, 1975: 23-26.

SERSTNĚVA, T. A.: Pokazateli uglevodnogo obmena u zimujuščich segoletkov karpa. Izvestija GosNIORCH, Leningrad, 81, 1972: 27-29.

SERSTNĚVA, T. A.: Dinamika pokazatelej uglevodnogo obmena u kapra Cyprinus carpio L. v period zimovky. Vop. ichtiol., 91, 1975: 324-331.

ŚILER, R. - VÁCHAL, J. - VINŠ, J.: Matematika v chovatelské praxi. SZN Praha, 1967, $238 \mathrm{p}$. 
VAVRUŠKA, A. - JANEČEK, V. st.: Sušina, tuk, dusíkaté látky a popeloviny v mase kapra. Bulletin VƯRH Vodňany, 9, 1973: 26-31.

WAITZENEGGER, M. - SERFATY, A.: Mise en évidence d'un rythme endogene annuel dans la réactivité de la carpe a un appart adrénalinique. Hydrobiologia, 29, 1967: 490-494. WITTENBERGER, C. - DIACIUC, I. V.: Effort metabolism of lateral muscles in carp. J. Fish. Res. Bd. Can., 22, 1965: 1365-1406. 